\title{
MANAGEMENT DEFICIENCIES IN THE SMALL SCALE MANUFACTURING INDUSTRIES IN SRI LANKA: A CASE STUDY ON RATNAPURA DISTRICT
}

\section{By}

H. M. S. Priyanath.

This thesis was submitted to the Faculty of Graduate Studies of the University of Sri Jayewardenepura in partial fulfilment of the requirements for the Degree of Master of Arts (Economics).

Registration No. : A 19334
Index No.

September, 1998 


\section{ACKNOWLEDGEMENTS}

The debt which I owe the many individuals and institutions who provided advise and support in the writing of this thesis is very great. It is with pleasure that I single out the most important of these for mention here.

Numerous thanks are naturally due to the advice and encouragement provided by my supervisors Professor P. Wilson, Vice Chancellor and Mr. H.H.D.N.P.K. Opatha, Senior Lecturer, Department of Business Administration of the University of Sri Jayewardenepura. I extend my most grateful acknowledgements for their help throughout this writing. And also I would like to thank Professor J.W.D. Somasundara, Vice Chancellor of the Sabaragamuwa University for giving valuable advice.

Here I would like to extend my special thanks to Mr. L.W.S. Kularatne, Mr. C. Disanayaka and Miss. S. D. K. Dharmadasa for sacrificing their valuable time in assisting me to complete the thesis. Finally I thank Professor Rajiva Wijesinha, Dr. N.D. Weeratunge Starkloff, and Father T. Jayawardena at the Sabaragamuwa University for their help in writing this thesis. 


\section{CONTENTS}

$\begin{array}{lr}\text { Acknowledgements } & \text { Page No } \\ \text { Contents } & \text { ii } \\ \text { List of tables } & \text { iii } \\ \text { Figure } & \text { vi } \\ \end{array}$

$\begin{array}{lll}\text { Chapter } 01 \text { Introduction } & 1-8\end{array}$

1.1. Introduction of the study 1

1.2. Objectives of the study 5

1.3. Methodology and data sources 5

1.4. Chapter outline 6

1.5. Limitations of the study - 7

\section{Chapter 02 Definition, Role and Importance of Small Scale} Manufacturing Industries

2.1. Definitions for Small Scale Manufacturing Industries (SSMIs). 9

2.2. Importance and role of SSMIs 11

2.3. Importance of management for the development of SSMIs 16

2.4. Importance of SSMIs in Sri Lanka 19

2.4.I. Historical perspective 19

2.4.II. Industrial polioy and development of SSMIs in post independent

2.4.III. Contribution to GNP 27

2.4.IV. Employment generation 29

2.5. Composition of SSMIs in Sri Lanka 30

2.6. Institutional assistance for the promotion of SSMIs in Sri Lanka 35 


\section{Chapter 03 Study area and profile of Small Scale Manufacturing Industries and Entrepreneurs}

3.1. Geographical location of the study area

3.2. Socio-economic background of the study area

3.2.I. Population

3.2.II. Agriculture

3.2.III. Education and health

3.2.IV. Infrastructure

3.3 SSMIs in the Ratnapura district

3.3.I. Dispersion of SSMIs in the district

3.3.II. Composition of SSMIs in the Ratnapura district (Employees between 5 and 24)

3.4 Profile of SSMIs in the Ratnapura district

3.5 Profile of small entrepreneurs

\section{Chapter 04 Management Deficiencies in Small Scale Manufacturing} Industries in Sri Lanka

4.1. Deficiencies in planning

4.1.I. Non achievement of goals

4.2 The weaknesses in the organizational structure

4.3 Weaknesses in staffing

4.4 Weaknesses in directing

4.5 Weaknesses in controlling

4.6 Deficiencies in production management

4.7 Weaknesses in marketing management

4.8 Weaknesses in financial management

4.9 Weaknesses in personnel management 
5.1. Summary

5.2. Conclusions

5.3. Recommendations

01 Questionnaire 98

02 DS division wise and category wise distribution of the sample 107

03 DS division wise dispersion of SSMIs in the Ratnapura district by industrial groups

04 DS division wise dispersion of employment in SSMIs in the Ratnapura district by industrial groups

05 Birth province of the entrepreneurs by industrial groups 110

06 Civil status of the entrepreneurs by industrial groups 


\section{LIST OF TABLES}

Table No.

Page No.

\section{Chapter 01}

1.1. Contribution to GNP and Growth rate of SSMIs $(1990-1996)$

\section{Chapter 02}

2.1. Definitions for SSMIs in selected countries

2.2. Employment and industrial establishment contributed by SSMIs in selected countries

2.3. Effects of management training by selected industries

2.4. Cottage industrial societies in 1953

2.5. Growth rate of SSMIs and its contribution to GNP at 1982 factor cost price ( $1987-1996$ )

2.6. Employment generation of SSMIs by industrial groups in $1983 \quad 30$

2.7. The relative size of small industry in 1989 (percentage in terms of No. of units, employments, output and value added)

2.8. The structure and composition of Sri Lanka's manufacturing sector (1989): classification by size of establishment

2.9. Composition of industries with less than 25 employees (percentage of No. of units, employment, assets, output and value added)

2.10. Total volume of credit disbursed under the SMI loan scheme up to the end of 1993 by financial institutions 


\section{Chapter 03}

3.1. Land use pattern in the Ratnapura district in 1996

3.2. No. of firms and employment of SSMIs by divisional secretariat divisions in 1996

3.3. No. of units and employment of SSMIs by industrial groups (1996)

3.4. No. of units and employment of food and beverages industries in 1996

3.5. No. of units and employment of mineral production - 1996

3.6. DS division wise dispersion of SSMIs in the Ratnapura district by industrial groups in 1996

3.7. DS division wise dispersion of employment in SSMIs in the Ratnapura district by industrial groups in 1996

3.8. No. of units and employment of Textile wearing and leather production in 1996

3.9. Small industrial units and employment (Employees between 5 - 24) by industrial groups

3.10. Years of establishment of industries by industrial groups

3.11. Ownership of the firms by industrial groups

3.12. Opening capital of the firms by industrial groups

3.13. Source of Opening capital of the firms by industrial groups

3.14. Nature of employment by industrial groups

3.15. Profitability of the firms by industrial groups

3.16. Age composition of the entrepreneurs by industrial groups

3.17. Ethnicity and religions of the entrepreneurs by industrial groups

3.18. Number of dependence of the entrepreneurs by industrial groups

3.19. Educational qualifications of the entrepreneurs by industrial groups 
3.20. Source of technical and craft skills of the entrepreneurs by industrial groups

3.21. Sources of management and administrative skills of entrepreneurs by industrial groups

\section{Chapter 04}

4.1. Planning for future development of SSMIs by industrial groups 68

4.2. Weaknesses in planning of SSMIs by industrial groups 68

4.3. Major goals of entrepreneurs by industrial groups 70

4.4. Achievements of goals of entrepreneurs by industrial groups 71

4.5. Various problems faced by the entrepreneurs 71

4.6. Distribution of management responsibilities among employees 73

4.7. Distribution of major responsibilities among the workers by industrial groups

4.8. The qualifications for the recruitment of employees in the SSMIs by industrial groups $\quad 76$

4.9. Methods applied to motivate of employees by industrial groups 78

4.10. Degree of planning of production process by industrial groups 79

4.11. Planning of production process by industrial groups

4.12. Utilization of planning for marketing management by industrial groups

4.13. Utilization of planning for financial management by industrial groups

4.14. Method of book keeping of the entrepreneurs by industrial groups 


\section{FIGURE}

\section{Chapter 03}

Figure 3.1. Ratnapura district with divisional secretariat boundaries 


\section{CHAPTER 01}

\section{INTRODUCTION}

\section{I.I Introduction of the Study}

Many nations in the developed and developing countries have recognized the importance and promotion of Small-Scale Manufacturing Industries (SSMIs). Consequently, they have devoted their attention towards the development of SSMIs because they play a significant role for their rapid development. SSMIs perform as a useful vehicle for the economic growth of countries because they have capacity to achieve rapid economic growth fast, while generating a considerable extent of employment opportunities. Promotion of SSMIs results in an increase of the industrial output of a country and thereby increases the share of the industrial output in GNP and finally it may enable the country to maintain a significant economic development together with a rapid industrialisation. Economic development of well developed industrial countries like Japan, Germany, the United States of America, the United Kingdom and also newly industrialised developed countries like Taiwan, South Korea were initially based on SSMIs.

The role played by the SSMIs is significant in many developed countries, for instance; the development of Japan in the early half of the $19^{\text {th }}$ century was initially based on SSMIs. SSMIs comprise a significant portion of the Japanese economy and perform an important role to the sector and has formulated policies to assist in its development. SSMIs in Japan still supply a large amount of component and intermediate products for the large industries and 65 per cent of SSMIs in Japan perform as sub contractors. In addition, it is also significant that they contribute 40 percent of industrial export (United Nations, 1985. p.72), it shared 87.2 per cent of total industrial employment and 80 per cent of industrial establishment (Reddy, 1991, p. 1-3). 
The importance of SSMIs is significant not only for the developed countries but also for the developing countries. In India, for instance, there are 1.7 million units of SSMIs functioning all over the country and they comprise half of the total industrial establishment (Rao and Nagaiya, 1991, p.12). In 1990, a half of the industrial employment has been contributed by SSMIs (Jalal, 1991, p.80), and they contribute 22.6 percent of total export earnings (Rao, \& Nagaiya, 1991, p. 13).

Development of SSMIs is significant in the developing countries like Sri Lanka, which suffered from problems of unemployment, lack of investment etc. SSMIs can develop using a very limited amount of capital assets and simple techniques. They help to solve unemployment problem to a considerable extent and SSMIs create more employment opportunities than that of large industries, since they are labour intensive industries. Resources dispersed all over the country can be utilised efficiently and economically in developing SSMIs and it helps to develop the rural sector as well. Problems of income inequality, balance of payment, lack of capital, technology etc can be solved by promoting SSMIs, and they help to increase countries' national income, thereby enhancing the living standard of the people. So the development of SSMIs in developing countries like Sri Lanka is very significant.

All the governments in Sri Lanka have recognised the importance of developing SSMIs after independence. In 1952, the World Bank recommended that the government should assist to develop SSMIs rather than the large-scale industries (Karunarathne, 1973. p. 28). Governments elected in 1970 and 1977 provided a major place to promote SSMIs, in their development plans. In 1990, the government highly supported, in developing SSMIs through "Janasaviya" programme. In addition, government institutions like the Industrial Development Board (IDB), Ministry of Youth Affairs, Department of Small Industries etc and various non-government institutions. usually pay their attention towards the promotion of SSMIs providing financial, technical, marketing, training and assistance. Furthermore, financial institutions in Sri Lanka provided Rs. 12.036 millions credit for SSMIs under the Small and Medium Industry Loan Scheme during the period 
between 1979-1998. (Central Bank of Sri Lanka, 1998, p. 123). Though government and non-governmental organisations paid attention to the promotion of SSMIs in Sri Lanka, they contribute a very small portion to the GNP (1.5 per cent in 1996). Table 1.1 shows that the annual growth rate of SSMIs was nearly 06 per cent during the recent four years.

Table 1.1 Contribution to GNP and Growth Rate of SSMIs (1990 - 1996)

\begin{tabular}{|c|c|c|c|}
\hline \multirow{2}{*}{ Year } & \multicolumn{2}{|c|}{ Contribution to GNP } & \multirow{2}{*}{ Annual Growth Rate } \\
\cline { 2 - 3 } & Rs. Million & $\%$ & 3.5 \\
\hline 1990 & 960 & 0.77 & 10.2 \\
\hline 1991 & 1065 & 0.86 & 88.5 \\
\hline 1992 & 2007 & 1.45 & 5.6 \\
\hline 1993 & 2120 & 1.43 & 6.2 \\
\hline 1994 & 2251 & 1.44 & 7.1 \\
\hline 1995 & 2410 & 1.45 & 6.3 \\
\hline 1996 & 2562 & 1.50 & \\
\hline
\end{tabular}

Annual growth rates of SSMIs in 1991 and 1992 were recorded at a very high rate because the government highly assisted the SSMIs under the poverty alleviation programme 'Janasaviya'. But this growth was not sustained and after 1993, it has decreased again. Lifetime of most SSMIs is very short and growth of most industries was very slow. Major reasons for the low growth rate and short lifetime are the problems and difficulties. Lack of capital assets, low technological knowledge, poor managerial knowledge, marketing problems etc directly caused the less growth of SSIs in Sri Lanka (Central Bank, 1996 p. 151).

In order to overcome these problems and obstacles faced by SSMIs, an efficient and effective management is needed. It is evidenced that growth of most industries depends on efficient management. Efficient management can satisfactorily face any challenge 
obstacle; problems coming from external and internal environment of industry. Entrepreneurs can achieve their goals if there is an efficient management (Cyril, 1984 p. 13). If management process of the industry is efficient, production of SSMIs, increases due to the decrease of cost of production. Decrease the cost of production due to management efficiency directly causes to shift the industrial supply curve to the right showing the increase of production (Howord, 1991, p. 31). SSMIs can develop by enhancing management skills of the small entrepreneurs.

Some countries like India, Japan, Indonesia, Taiwan, etc launched various long-term management programmes for the enhancement of management knowledge of small entrepreneurs. In Indonesia, growth rate of SSMIs was less than 4 per cent before 1978 and it was increased to more than 7 per cent during the five-year plan period 1978-1982. One major reason for the growth was that the Indonesian government provided management training for the enhancement of management skill of small entrepreneurs (United Nations, 1985, pp. 40-55).

According to the Indonesian experience, SSMIs can be developed in Sri Lanka too using better management. So this study examines the management deficiencies of SSMIs in Sri Lanka and how SSMIs develop by overcoming such problems. In Sri Lanka, it is rather difficult to distinguish between entrepreneurs and managers. The entrepreneurs handle the management process of SSMIs themselves. According to the field survey conducted in the Ratnapura district, a number of management deficiencies could be identified and basic management functions such as planning, organising, staffing, controlling, etc that are not properly practiced in most SSMIs in the study area. Most entrepreneurs of SSMIs do not have sufficient management knowledge as a result; growth of SSMIs may be lessened. By improving management knowledge of small entrepreneurs, SSMIs can be developed efficiently in Sri Lanka. 


\subsection{Objectives of the study}

Major objectives of the study are;

1). To explain the structure of small scale manufacturing industries in the study area.

2). To analyse the deficiencies related to the basic management process of SSMIs in Sri Lanka.

3). To make recommendations to develop SSMIs efficiently by overcoming deficiencies in the management process.

\subsection{Methodology and Data Sources}

In order to fulfil the objectives of the study, the descriptive method of analysis has been used. Since this is an in-depth analysis of SSMIs, the study was totally based on the primary sources of data. However, the analysis was supplemented with the data from the secondary sources when and wherever it was needed and demanded.

Since the Sabaragamuwa University always encourages research within the province, the Ratnapura district has been selected in collecting primary data. The Industrial Development Board (IDB) has already prepared an ' Inventory of SSMIs in the Ratnapura district'. This inventory was taken as a bench mark for the sample. According to the IDB study, 3703 of SSMIs were dispersed all over the Ratnapura district (see table 3.6). However, it is noteworthy that the definition used by the IDB was not very specific and includes even the self-employment projects as SSMIs. Therefore for the purpose of this study, industrial units, which employ between 5 to 24 persons, were defined as SSMIs. This refinement of the definition reduced the total number of SSMIs from 3703 to 285 units. In order to keep the sample within manageable proportions, 20 percent of the SSMIs i.e. 57 industrial units were selected. 
According to the IDB study, SSMIs had been spread out unequally among the 16 Divisional Secretariat (DS) areas in the Ratnapura district. Therefore, by distributing the total number of selected sample of 57 SSMIs proportionately (20 percent of SSMIs in each DS division), an attempt was made to avoid high concentration of SSMIs in some DS divisions such as Kuruwita, Ratnapura, Balangoda and Embilipitiya because the study attempts to show the full picture of the deficiencies of management (The DS area wise and category wise distribution of the sample is given in annexture 02).

For the purpose of classifying SSMIs, two digit International Standard of Industrial Classification (ISIC) has been used for this study. In order to facilitate the comparison the randomly selected 57 SSMIs were categorised into nine industrial groups (31 to 39) specified in the ISIC.

In order to collect data from the selected sample an open-ended questionnaire was used, answers are taken only from interviewing entrepreneurs or the general manager (if available). To assert validity and reliability of data all the answers provided by the interviewees have been written in details. Furthermore in order to ascertain SWOT (Strengths, Weaknesses, Opportunities and Threats) the process of production, method of book keeping, marketing, advertising and personnel management etc were studied personally in each SSMI.

\subsection{Chapter Outline}

The study consists of five chapters. Chapter one deals with the introduction of the study, objectives, data sources and methodology, organisation of the study and limitations.

Chapter two discusses definitions used by a few selected countries and Sri Lanka, role of SSMIs in economic development, importance of management for the SSMls, development of SSMIs pre and post independence in Sri Lanka. In addition, importance 